\title{
Validita a reliabilita výskumných nástrojov: princípy a reálna prax
}

\author{
Peter Gavora
}

Univerzita Tomáše Bati ve Zlíně, Fakulta humanitních studií, Centrum výzkumu

Redakci zasláno 1. 4. 2013 / upravená verze obdržena 4. 6. 2013 / k uveřejnění přijato 24. 6. 2013

\begin{abstract}
Abstrakt: Článok odpovedá na otázku, ako sa uplatňujú v praxi princípy zistovania validity a reliability, ktoré udávajú renomované učebnice metodológie. Prvé dve časti príspevku načrtávajú teoretický rámec a opisujú koncept validity a reliability. Nasledujúce časti vysvetlujú proces analýzy a uvádzajú jej výsledky. Z časopisu The Journal of Educational Research bolo náhodným spôsobom vybratých 56 štúdií. Vel'ká väčšina (91\%) výskumných nástrojov v nich boli posudzovacie škály a testy, zvyšok boli dotazníky, pozorovacie schémy a interview. Na prekvapenie bola validita zdokumentovaná len u $26 \%$ nástrojov, zvyšok nástrojov boli štandardizované testy, alebo sa autori spoliehali na zrejmú (face) validitu. U posudzovacích škál sa použila konštruktová validita zistená pomocou faktorovej analýzy. Obsahová validita a face validita sa použili pri testoch, dotazníkoch a interview. Kombinované zdroje validity (napr. konštruktová spolu so súbežnou alebo diskriminačnou) sa použili vel'mi málo, čo považujeme za nedostatok vo validizačnom procese. Reliabilita bola uvedená pri 80 \% nástrojoch. Najfrekventovanejší spôsob bola Cronbachova alfa u posudzovacích škál. Zhoda medzi posudzovatel'mi sa použila pri pozorovaní a testoch. Test-retest sa použil pri overovaní, či je merací nástroj na pretest-posttest stabilný v priebehu času. Koeficienty reliability väčšinou presahovali 0,80. Pri analýze štúdií sa potvrdilo, že pri posudzovaní adekvátnosti validizácie a reliabilizácie je potrebné silne prihliadat' k špecifickým podmienkam konkrétneho výskumu.
\end{abstract}

Klúčové slová: metaštúdia, validita, reliabilita, výskumný nástroj, výskumná štúdia

Validita a reliabilita sú základné pojmy psychometrie, teórie vyjadrujúcej princípy a postupy objektívneho merania premenných veličín súvisiacich s človekom. Psychometria má za sebou storočnú tradíciu, ktorú založil F. Galton. Jej teóriu postupne rozvinuli osobnosti zaoberajúce sa meraním inteligencie, d’alších schopností, ako aj osobnostných čŕt (A. Binet, L. L. Thurstone, K. Pearson, W. Stern, Ch. Spearman, R. B. Cattell, L. J. Cronbach a d'alší). Validita a reliabilita sa viazala najprv na testy, ktoré boli sprvoti najpoužívanejšími a najrozvinutejšími objektívnymi výskumnými nástrojmi, neskôr k nim pri- 
budli i dotazníky, posudzovacie škály a štruktúrované pozorovanie. Výskumné nástroje využívajúce tieto metódy zberu dát sa použili v experimentoch, t.j. výskumnej metóde, ktorá sa najviac chce priblížit' modelu výskumu reprezentovanému prírodnými vedami.

Ak skúmame pohyb v metodológii za posledných 30-40 rokov, zistíme, že v kvantitatívnom výskume zd’aleka nebol taký dynamický ako v kvalitatívnom výskume. $V$ kvantitatívnom výskume môžeme spomenút' napríklad novú teóriu testových odpovedí (item response theory), Raschov model merania, zist'ovanie vel'kosti účinku (effect size), ktoré sa stalo základom pre metaanalýzy a v štatistike hierarchickú regresnú analýzu. S príchodom počítačov sa rozvinulo adaptívne testovanie a elektronické administrovanie dotazníkov a posudzovacích škál, kde papier a ceruzku nahradila klávesnica a obrazovka. Zmenil sa však nielen nosič, ale aj forma odpovedí a spôsob navigácie vo výskumnom nástroji, zrýchlilo a zautomatizovalo sa spracovanie dát. Vel'ké zmeny priniesli možnosti použitia videa pri pozorovaní (v ČR najmä Janík a jeho skupina - Janík \& Miková, 2006, Najvar et. al., 2011). Nové impulzy pre komparatívny kvantitatívny výskum priniesli medzinárodné štúdie gramotností (čitatel'skej, matematickej, prírodovednej). Istý posun nastal v chápaní validity a reliability výskumného nástroja, o ktorom píšeme v nasledujúcej časti.

Kvantitatívny výskum si udržal silné postavenie vo výskumných štúdiách na celom svete, aj ked' sa objavil jeho nový súper - kvalitatívny výskum založený na úplne inej filozofii a z nej odvinutej metodológie. Kvalitatívna metodológia najprv predstavovala rivala, neskôr sa stala partnerom a napokon spojencom kvantitatívneho výskumu. Objavili sa výskumné projekty, v ktorých bola prvá fáza kvantitatívna, druhá kvalitatívna a vice versa, alebo obidve fázy prebiehali simultánne (pozri Hendl, 2005). Neskôr koexistencia týchto dvoch prístupov poskytla pôdu na rôzne formy a úrovne prelínania. Napríklad pri naratívnej metóde, ktorá je jednou z vlajkových lodí kvalitatívneho prístupu, sa objavil i jej kvantitatívny variant - kvantitatívna naratíva. Naopak, zo štruktúrovaného dotazníka, ktorý je typickým predstavitelom kvantitatívneho prístupu, sa môžu konštruovat' „kvalitatívne“ naratívy. Sú založené skôr na časových a procesných charakteristikách než na interpretatívnych a subjektívne významových pozíciách a slúžia na vytvorenie „generických životných príbehov“" (Elliot, 2012).

V situácii dynamického metodologického vývoja je dobré vrátit’ sa k základným kameňom kvantitatívneho výskumu a skontrolovat' stabilitu jeho štan- 
dardných postupov uplatnených vo výskumnej praxi. $\mathrm{V}$ tomto príspevku to uskutočníme prostredníctvom jeho dvoch klúčových konceptov - validity a reliability.

\section{Koncept validity a reliability}

Validita a reliabilita sú klúčovými požiadavkami kladenými na výskumný nástroj v kvantitatívnom výskume. Spolu s dalšími vlastnostami, ako je objektivita, verifikovatel'nost' a štatistická zovšeobecnitel'nost' zistení vytvárajú piliere toho, čo nazývame dobrý kvantitatívny výskum.

Validita sa $\mathrm{v}$ minulosti definovala ako vlastnost' výskumného nástroja umožňujúca zist'ovat' to, čo výskumník mieni zistovat'. Ak chce výskumník zistit' spokojnost' učitel'ov s profesiou, do výskumného nástroja vloží položky, ktoré zahrňujú rôzne aspekty práce učitela a dá učitelom možnost', aby tieto aspekty hodnotili na škále spokojnost'-nespokojnost'. Z obsahového hladiska potom možno kvalifikovat' tento výskumný nástroj ako validný na zistovanie spokojnosti učitel'a s profesiou. Novšia koncepcia validity výskumného nástroja (Standards..., 1999) ${ }^{1}$ posunula tento koncept d’alej a výskumník sa na základe zistení pýta, ako môže interpretovat' odpovede konkrétnej skupiny učitel'ov z hladiska ich spokojnosti s profesiou a aké má dôkazy na doloženie svojej interpretácie. Úroveň validity určitého výskumného nástroja je teda daná interpretačnými možnostami jeho zistení. Dôležitú úlohu pri nej hrá vyvodzovanie, ktoré výskumník uskutočňuje na základe údajov zistených výskumným nástrojom.

Výskumník sa môže rozhodnút' pre rôzne spôsoby („zdroje“ v terminológii Standards..., 1999) validity. Z hladiska toho, ako daný výskumný nástroj odráža obsah určitej výchovno-vzdelávacej oblasti možno usudzovat' o obsahovej validite. Z hladiska toho, do akej miery výskumný nástroj predikuje budúci stav alebo zist'uje súvislost' s danou vlastnostou meranou iným nástrojom, možno usudzovat' o kritériálnej validite. Z hl'adiska toho, aký psychický konštrukt výskumný nástroj sleduje, možno usudzovat' o jeho konštruktovej validite.

Reliabilita vyjadruje súčasne presnost' a spol'ahlivost' zistených údajov. Výskumník má možnost' zvolit’ si rôzne spôsoby reliability podl'a toho, aké

Ide o štandardy pre pedagogické a psychologické meranie, ktoré vydávajú spoločne Americká asociácia pre pedagogický výskum, Americká psychologická asociácia a Národná rada pre meranie vo výchove, a ktoré sú v USA rešpektovanou normou pre tvorbu a používanie výskumných a diagnostických nástrojov. 
závery chce vyslovit'. Ak chce vyslovit' záver o tom, aké stabilné sú údaje získané pomocou výskumného nástroja, potom si zvolí opakovanie administrácie s tými istými subjektmi po časovom odstupe (test-retest reliability). Ak chce vediet', do akej miery možno jeho dáta zovšeobecňovat' na podobné úlohy, použije alternatívne formy výskumného nástroja s tými istými subjektmi. Ak chce vediet', do akej miery sú dáta zhodné, ked' ich vyhodnocujú viacerí hodnotitelia, porovná výsledky týchto hodnotitel'ov (inter-scorer reliability). Ak chce vediet', do akej miery je jeho výskumný nástroj homogénny (t. j. či sa jeho položky dostatočne koncentrujú na cielovú vlastnost'), vypočíta korelácie medzi každou položkou a nástrojom ako celkom. Aby bola reliabilita dostatočná, musia byt' korelácie dost' vysoké (Salvia \& Ysseldyke, 1998, s. 151-152). ${ }^{2}$ Vypočíta sa tiež index vyjadrujúci vnútornú konzistenciu celého výskumného nástroja, obyčajne je to koeficient alfa ${ }^{3}$.

Informácie o úrovni validity a reliability pomáhajú výskumníkovi rozhodovat' sa o tom, či môže byt' s výskumným nástrojom spokojný, alebo či ho má zlepšovat', prípadne odmietnut'. Tieto údaje potrebuje výskumník na začiatku výskumu. Ale otázky validity a reliability ho musia zaujímat’ aj pri spracovaní a interpretovaní výskumných dát. Dáta totiž musí vzt’ahovat' vzhl'adom $\mathrm{k}$ vlastnostiam výskumného nástroja.

Obidve tieto vlastnosti výskumného nástroja sú relatívnymi mierami. Nemôžeme tvrdit', že je výskumný nástroj validný alebo je nevalidný, ale aký je stupeň jeho validity. Tiež je zrejmé, že výskumný nástroj môže byt' viac validný na jeden účel a menej validný na iný účel. To isté platí o reliabilite. Vždy ide o údaj o konkrétnom výskume s konkrétnymi výskumnými osobami v konkrétnych podmienkach administrácie, to znamená, že údaje získané tým istým výskumným nástrojom sa môžu v rôznych výskumoch líšit'. $\mathrm{V}$ dobre overenom výskumnom nástroji a pri podobných skúmaných osobách a pri podobných podmienkach administrácie by však rozdiely nemali byt' vel'ké.

Okrem výrazov validita a reliabilita budeme $\mathrm{v}$ tomto príspevku používat' aj výrazy validizácia a reliabilizácia, ktoré sa týkajú procesu smerujúcemu k získaniu informácií o týchto vlastnostiach výskumných nástrojov. Validita a reliabilita sú výslednými produktmi tohto procesu.

2 Nie však extrémne vysoké (napr. nad 0,95), pretože to naznačuje, že položky sú takmer totožné. A to zase spochybňuje validitu nástroja.

3 Klasici metodológie výskumu Nunnally a Cronbach (cit. podla Kline, 2000, s. 43) tvrdili, že je to najlepší index reliability vôbec. Kedže je jeho výpočet aj pohodlný, spájajú sa v ňom dve ideálne vlastnosti. 


\section{Ciele štúdie}

Metodologické princípy zist'ovania validity a reliability výskumného nástroja, ich predpoklady, základné vlastnosti a normy dostatočnej validity a reliability sú známe z renomovaných publikácií (napr. Standards..., 1999; Kline, 2000; Hopkins, 1998). Aká je však skutočná prax? Ako sa tieto princípy uplatňujú v reálnych výskumoch s konkrétnymi výskumnými nástrojmi?

Odpoved' na tieto otázky je možné získat' prostredníctvom analýzy produktov výskumníkov, teda publikovaných výskumných štúdií a správ. V tomto príspevku analyzujeme časopisecké výskumné štúdie, ktorých výber je uvedený nižšie. Žáner tohto príspevku charakterizujeme ako metaštúdiu, t. j. štúdiu, ktorá súhrnným spôsobom podrobuje analýze a hodnoteniu väčší počet iných štúdií z vopred stanovených hl'adísk.

Pri analýze sme sa zamerali na tieto otázky:

1. Aké druhy výskumných nástrojov sa $\mathrm{v}$ štúdiách použili $\mathrm{a} v$ akej proporcii?

2. Kol'ko výskumných nástrojov obsahujú jednotlivé štúdie?

3. Aké spôsoby validizácie a reliabilizácie sa použili?

4. Bola validizácia a reliabilizácia použitého výskumného nástroja dokladovaná v danej výskumnej štúdii takým spôsobom, aby sa mohlo usudzovat', že sa uskutočnila vhodne a korektne?

5. Bola validita a reliabilita použitého výskumného nástroja dostatočne vysoká vzhl'adom k platným princípom?

Prvé dve otázky sa týkajú informácií o zastúpení výskumných nástrojov v jednotlivých štúdiách. Mapujú základný kontext, v rámci ktorého bude prebiehat' d’alšia analýza. Majú ukázat', ktoré typy výskumných nástrojov prevládajú a, naopak, ktoré sú slabo zastúpené (a prečo). Tretia otázka smeruje ku kategorizácii jednotlivých spôsobov validity a reliability. Štvrtá a piata otázka smeruje k jadru príspevku a je zameraná na zistenie, do akej miery je prax validity a reliability verná platným metodologickým princípom.

\section{Výber štúdií na analýzu}

Odpoved' na naše výskumné otázky možno nájst' v publikovaných výskumných správach alebo časopiseckých štúdiách. $\mathrm{V}$ tomto príspevku sme sa 
z pragmatických dôvodov sústredili na časopisecké štúdie - sú dostupnejšie než výskumné správy.

Pri ich výbere je možné postupovat' tak, že sa zvolí pedagogický časopis (alebo niekol'ko časopisov) rôznej orientácie a tieto sa podrobia analýze z uvedeného hladiska. Podmienkou však je, aby časopis publikoval dostatočné množstvo výskumných štúdií. Ak je týchto štúdií málo, analýza neposkytne dostatočný obraz o realite. Okrem toho výskumné štúdie musia obsahovat' opis zist'ovania validity a reliability použitých výskumných nástrojov, bez nich by totiž nebolo čo analyzovat'. Kritérium dostatočného množstva výskumných štúdií plnia mnohé, najmä zahraničné časopisy. Po zvážení možností sme vybrali jeden z nich, ktorý mal aj dalšie ukazovatele výborné.

Zvolili sme časopis The Journal of Educational Research, a to z týchto dôvodov:

1. Časopis vychádza dlhodobo (v r. 2013 ide o 106. ročník).

2. Rukopisy sú prísne recenzované.

3. Publikujú v ňom významní výskumníci.

4. Aj ked' v ňom prevládajú severoamerickí autori, redakcia uverejnila aj príspevky z iných geografických oblastí (Európa, Austrália, Ázia).

5. Časopis vychádza v známom vydavatel'stve Taylor and Francis.

6. Takmer všetky príspevky sú zamerané na empirický výskum, takže časopis poskytne dostatok materiálu na analýzu.

Pri výbere konkrétnych štúdií sme postupovali nasledovne. V ročníkoch 2005, 2007, 2009 a 2011 sme zoradili štúdie abecedne podla priezviska prvého autora. V každom ročníku sme vybrali prvých 15 štúdií, ktoré sa stali predmetom analýzy. Ak štúdia nezodpovedala kritériu, vybrali sme v poradí d’alšiu štúdiu. Kritériom bola orientácia na kvantitatívny výskum a použitie výskumného nástroja. Z výberu boli preto vyradené štúdie, ktoré obsahovali demografické analýzy, metaanalýzy a, samozrejme, kvalitatívne štúdie. Zo štúdií so zmiešaným, kvantitatívno-kvalitatívnym dizajnom bola predmetom analýzy len kvantitatívna čast'. Aby sme sa vyhli efektu opakovania pri výbere štúdií, autor mohol mat' vo výbere len jednu štúdiu, v ktorej bol uvedený ako prvý autor. 
Časopis je dostupný v databáze ProQuest Central (prvé tri zvolené ročníky) a na webovej stránke časopisu (ročník 2011).Z posledného ročníka bolo vol'ne dostupných, resp. zodpovedalo kritériu len 7 štúdií. ${ }^{4} V$ starších ročníkoch boli niektoré štúdie nečitatel'ne naskenované, tie nemohli byt' analyzované (poradie výberu sa posunulo). Za poznámku stojí, že časopis len výnimočne uverejňuje štúdie, ktorých hlavným cielom je vývoj nového výskumného nástroja a podrobná správa o jeho validizácii a reliabilizácii. Publikuje hlavne štúdie, v ktorých sa výskumný nástroj používa primárne na zber výskumných dát, pričom opis a interpretácia týchto dát tvorí jadro výskumnej štúdie.

Celkove súbor zahrňuje 52 výskumných štúdií, v ktorých sa použilo 174 výskumných nástrojov.

\section{$4 \quad$ Zistenia}

\subsection{Druhy výskumných nástrojov}

Zistenia o druhoch použitých výskumných nástrojov informujú čitatelov o metodologických trendoch, ktoré sa presadzujú v danom časopise. Ale druhy výskumných nástrojov v štúdiách časopisu vypovedajú nepriamo aj o tom, aké mali autori štúdií možnosti pri ich validizácii a reliabilizácii, resp. ktorým možnostiam dali prednost'. Niektoré výskumné nástroje sa totiž prednostne validizujú a reliabilizujú jedným spôsobom, iné druhým. Základné údaje o počte jednotlivých druhov výskumných nástrojov v analyzovaných štúdiách vyjadruje Obrázok 1.

Kvôli odstráneniu terminologickej nejednoznačnosti uvedieme najprv, čo rozumieme pod konkrétnym názvom výskumného nástroja. Posudzovacia škála znamená nástroj obsahujúci intervalové alebo poradové škály vo forme formulára. Umožňuje vyjadrovat' skóre za celý nástroj, alebo za jeho zložky (dimenzie). Dotazník znamená nástroj obsahujúci uzavreté alebo otvorené otázky. Niekedy bývajú v dotazníkoch aj škálové položky, ale málokedy prevládajú. (Štruktúrované) interview je, podobne ako dotazník, formou získavania informácií od respondentov v podobe otázok, avšak ústnym spôsobom.

4 Články z ročníkov 2012 a 2013 neboli dostupné v databáze ProQuest Central alebo v inej databáze a neboli ani vol'ne dostupné na webovej stránke časopisu. Vydavatel' poskytuje prístup k štúdiám z týchto ročníkov za poplatok USD 28 za jednu štúdiu. Vzhladom na to, že analýza týchto ročníkov by nepriniesla iný obraz o výskumných nástrojoch, ako bol ten z nižších ročníkov, považovali sme zakúpenie článkov z týchto ročníkov za nehospodárne. Preto sme ich analýzu neuskutočnili. 
U dotazníkov a interview sa vyjadruje frekvencia alebo percentuálne zastúpenie odpovedí. Výrazom test označujeme nástroj obsahujúci úlohy (položky) na meranie kognitívnych a psycho-motorických výkonov subjektov. Výsledok testu sa vyjadruje pomocou skóre. Pozorovacia schéma je systém kategórií, v rámci ktorých výskumník zaznamenáva frekvenciu, intenzitu, kvalitu alebo trvanie pozorovaných javov alebo procesov. Výsledok pozorovania sa vyjadruje numericky v podobe frekvencií, aritmetických priemerov, indexov atd. ${ }^{5}$

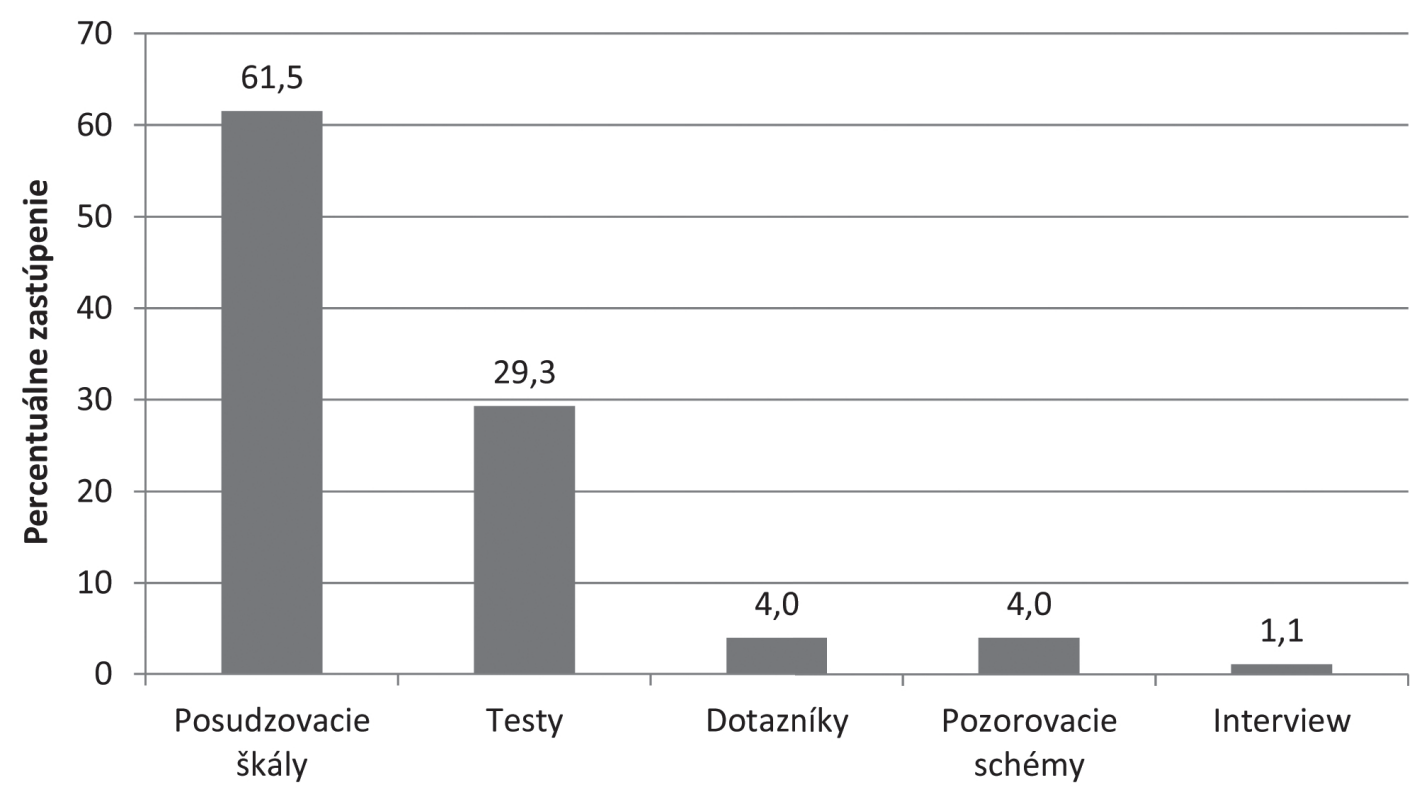

Obrázok 1. Druhy použitých výskumných nástrojov.

Ako vidno, vo výskumoch sa robustným spôsobom uplatnili dva druhy výskumných nástrojov - posudzovacie škály a testy. Tie spolu pokrývajú 90,8 \% použitých výskumných nástrojov. V 52 štúdiách našej vzorky sa posudzovacie škály použili 107-krát, testy 51-krát. V štúdiách boli vel'mi slabo zastúpené dotazníky, pozorovacie schémy a interview.

5 Terminológia súvisiaca s rôznymi druhmi výskumných nástrojov $\mathrm{v}$ angličtine je dost' komplikovaná. Slovenským výrazom dotazník sa obyčajne prekladajú tri anglické výskumné nástroje: questionnaire (dotazník), checklist, inventory (inventár), scale (škála). Zlé je aj to, že anglický výraz scale (v jednotnom čísle) znamená vlastne súbor škál, nie jeden výskumný nástroj založený na škálovaní. Niekedy sa vo význame súboru škál dokonca používa výraz test (napr. Test rodinného prostredia J. Senku, Záujmový test VRIOT, Test diferenciácie záujmov DIT a pod.). Sociometrický test (v terminológii J. L. Morena) je vlastne posudzovacia škála. Pri analýze výskumných štúdií sme sa usilovali zistit’ typické črty výskumného nástroja a podla nich ho kategorizovat' podla tu uvedených definícií. 
Otázkou je, prečo výskumníci preferovali posudzovacie škály a testy a, naopak, málo používali d’alšie druhy výskumných nástrojov. Výskumník si volí výskumné nástroje na základe ciela výskumu a výskumných otázok, na ktoré hladá odpovede. Pritom využíva všetky možnosti, ktoré mu empirický priestor dáva (subjekty výskumu a inštitúcie) a je zároveň nimi obmedzovaný. Posudzovacie škály predstavujú nesmierne široký potenciál možností na zist'ovanie vlastností osôb, procesov a produktov. V posudzovacích škálach, ktoré boli v našom súbore štúdií, sme našli vel'mi pestré zameranie. Tu je niekol'ko príkladov: miera integrácie inovácií do vyučovania učitel’om, osobnostné črty učitel'a, úroveň motivácie žiakov, postoje žiakov k vyučovaciemu predmetu, prístup žiakov k učeniu sa, miera pracovnej spokojnosti učitel'ov, metakognitívna uvedomenost' žiaka, vnímaná profesijná zdatnost' učitela, konštruovanie roly učitel'a, vzt'ah škola-rodina, školské prostredie, materiálne vybavenie školy.

Okrem možností hodnotit' široké spektrum vlastností je výhodou posudzovacích škál relatívne lahký spôsob zist'ovania reliability. Vypočíta sa pomocou koeficientu alfa, ktorý obsahujú softvéry na štatistické spracovanie výskumných dát (SPSS, Statistica). Pri výpočte je zároveň možné dat' príkaz na vypočítanie korelácie každej položky s nástrojom ako celkom (príp. s danou dimenziou). Ak je korelácia nízka, výskumník má možnost' pri príprave nástroja položku preformulovat’ alebo ju eliminovat', aby získal nástroj s vyššou konzistenciou, teda vyššiu reliabilitu. To je pomerne l'ahká procedúra, ktorá - okrem možnosti skúmania širokého spektra vlastností - silne favorizuje tento výskumný nástroj. Ako ukážeme d’alej, zistenie reliability posudzovacích škál pomocou koeficientu alfa bolo najčastejším spôsobom reliabilizácie v našom súbore štúdií.

Testy sa v našom súbore štúdií vyskytli v počte 51 , teda v priemere jeden test na jednu štúdiu. Pokial' ide o zameranie, boli to testy vedomostí a zručností z viacerých vyučovacích predmetov, testy gramotnosti na rôznej úrovni (pomenovanie písmen, dekódovanie, pomenovanie obrázka a pod.), testy divergentného myslenia, riešenia problémových úloh, predalgebraického myslenia, biligviálny test a pod. Mnohé použité testy boli štandardizované a bežne sa v USA používajú, napr. SAT, KeyMath Revised Normative Update, Indiana Statewide Test for Educational Progress, North Carolina End of Course Algebra a pod. Školstvo Spojených štátov, odkial' pochádzalo najviac výskumných štúdií, ktoré sme analyzovali, je výrazne výkonnostne orientované a testovanie je „denným chlebíčkom“ žiakov. To vysvetluje silné zastúpenie testov v našom súbore štúdií. 
Hoci sa dotazníky relatívne l'ahko konštruujú (obyčajne l’ahšie ako testy), nie sú zrejme u výskumníkov publikujúcich $\mathrm{v}$ tomto $\mathrm{v}$ časopise populárne preto, lebo majú menšie štatistické možnosti. Nástroje na pozorovanie sa zvyčajne konštruujú t'ažšie a zber dát je náročný na čas, podobne ako pri interview. Pravdepodobne sa preto použili menej často.

\subsection{Počet výskumných nástrojov v jednej štúdii}

Počet výskumných nástrojov $\mathrm{v}$ jednej štúdii vypovedá dostatočne silne o tom, aký široký bol výskumný záber. Pravdu povediac, zistenia o počte výskumných nástrojov $\mathrm{v}$ jednej štúdii boli pre nás väčším prekvapením, ako to, čo bolo hlavným predmetom analýzy, t. j. použité spôsoby a úroveň validity a reliability výskumných nástrojov.

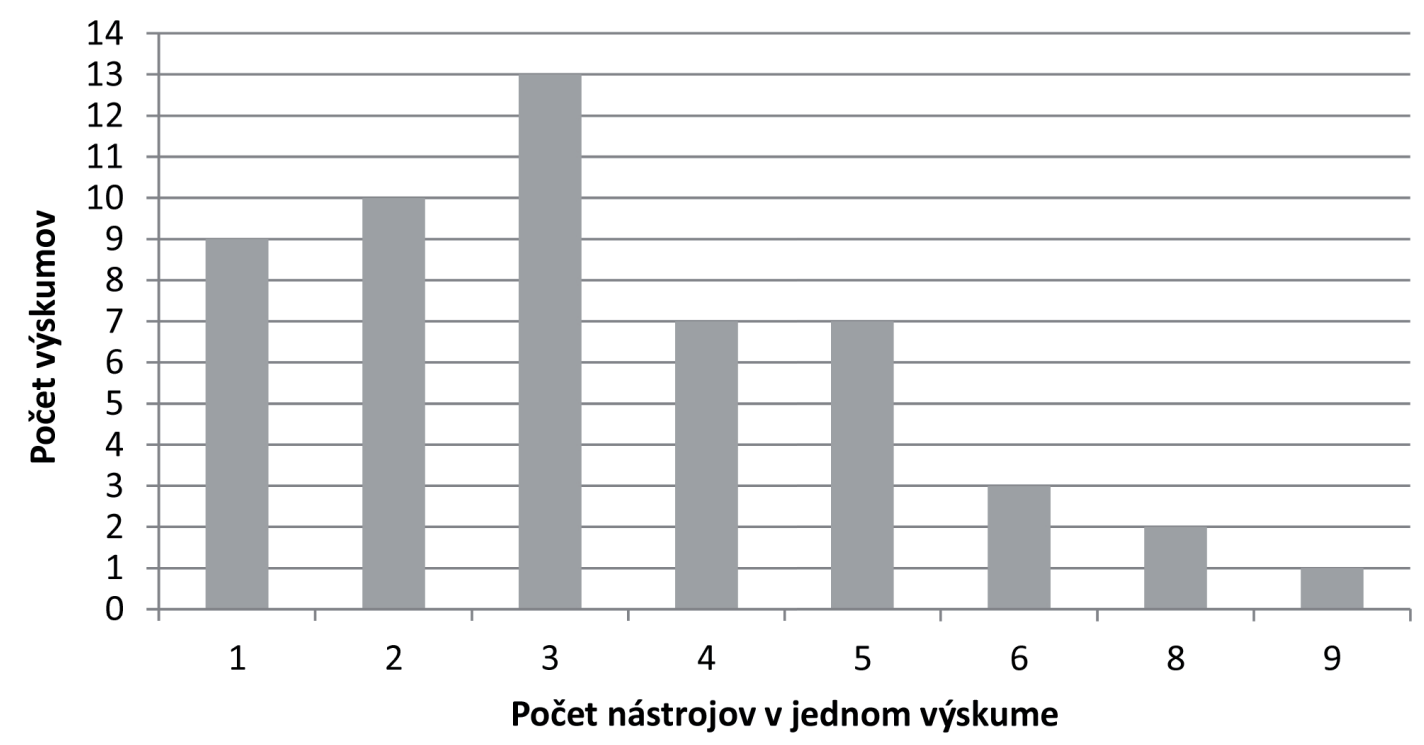

Obrázok 2. Počet výskumných nástrojov v jednom výskume.

Obrázok 2 ukazuje, že vo vel'kej väčšine štúdií sa použilo viac výskumných nástrojov ako jeden. $V$ priemere to bolo 3,3 výskumných nástrojov na jeden výskum. Len devät' štúdií z 52 malo jediný výskumný nástroj; na druhej strane boli v našej vzorke výskumy, ktoré mali 4 až 9 výskumných nástrojov.

Počet a druh výskumných nástrojov závisí od ciela výskumu a ten ukazuje, aké je široké (príp. hlboké) empirické pole, na ktoré sa výskum zameral. $\mathrm{Z}$ analýzy vyplýva, že časopis preferuje výskumy, ktoré danú problematiku skúmajú komplexne, berú do úvahy viaceré premenné a hladajú medzi nimi 
súvislosti. Na ilustráciu uvedieme výskum, ktorý je dost’ typický pre takéto zameranie.

C. Kohova et al. (2009) skúmali vplyv skupinového učenia sa na motiváciu a učenie sa žiakov. Zistovali názory žiakov o tom, či skupinová práca uspokojila ich potreby, ovplyvnila ich motiváciu a vytvárala dost' príležitosti na rozvoj zručností pre život. Výskumu sa zúčastnilo 588 žiakov stredných škôl a ich učitelia v Singapure. Výskumníci použili pät’ výskumných nástrojov adaptovaných z pôvodných anglických originálov:

- Posudzovacia škála motivácie (17 položiek).

- Posudzovacia škála uspokojovania potrieb (12 položiek).

- Posudzovacia škála skúseností s bádatel'skými úlohami (17 položiek).

- Posudzovacia škála metakognície (7 položiek).

- Posudzovacia škála percepcie výsledkov učenia sa (15 položiek).

Okrem toho v kvalitatívnej časti výskumu autori použili pološtruktúrované interview s učitel'mi.

Na doplnenie analýzy počtu výskumných nástrojov použitých $\mathrm{v}$ jednom výskume uvedieme, že vel'ká väčšina štúdií mala viac ako jedného autora; nebolo neobvyklé nájst' štúdiu, ktorá mala štyroch až šiestich autorov. To naznačuje možnú spojitost' medzi počtom použitých výskumných nástrojov a počtom autorov. Výskum mal často teamové zameranie z dôvodu koncentrácie síl výskumníkov a efektívneho využitia prostriedkov.

\subsection{Originálne a prevzaté výskumné nástroje}

Výskumné nástroje, ktoré sa použili v našom súbore štúdií, boli bud' vlastné (ich konštruktérmi boli autori štúdií), alebo boli prevzaté (vytvorili ich iní odborníci). Mohli to byt' výskumné nástroje použité v iných výskumoch, alebo to boli štandardizované nástroje poskytované rôznymi vydavatel'mi. Originálne výskumné nástroje boli zastúpené 47,1 percentami, prevzaté nástroje tvorili zvyšok (52,9\%). To, že prevzaté výskumné nástroje tvorili taký vysoký podiel, ukazuje, že výskumníci si mohli vyberat' z bohatej ponuky, ktorú mali k dispozícii. Možnost' prevzatia originálneho výskumného nástroja v rodnom jazyku je vel'kou výhodou, pretože ulahčuje prácu výskumníkov a umožňuje aj porovnávanie výsledkov rôznych výskumov realizovaných týmto nástrojom.

Prevzaté výskumné nástroje boli použité bez zmeny, alebo boli modifikované. Pri modifikácii výskumníci použili vel'mi rôznorodé stratégie: zme- 
nili znenie niektorých položiek nástroja, skrátili nástroj (vypustili niektoré položky), zlúčili dve dimenzie nástroja alebo prevzali len jednu dimenziu. Stávalo sa, že niekol'ko skrátených nástrojov zlúčili do nového nástroja, pričom si prispôsobili podla potrieb aj d'alšie vlastnosti, napr. rozsah a znenie škály v posudzovacích škálach. Táto pestrost' zásahov a odvaha manipulovat' s originálnymi nástrojmi nás tiež prekvapila, bola však obyčajne podložená dôkazmi o dostatočných psychometrických vlastnostiach modifikovaných nástrojov.

Ako ukážku výskumu založenom na množstve adaptovaných výskumných nástrojov uvedieme štúdiu H. J. Banga (2011). Autor skúmal, ako ovplyvňujú úroveň domáceho učenia sa žiaka činitele viažuce sa k samotnému žiakovi, jeho rodine a škole. Výskumu sa zúčastnilo 192 žiakov strednej školy z imigrantských rodín v USA. Autor použil sedem výskumných nástrojov, ktoré boli postupne žiakom zadávané:

- Posudzovacia škála angažovania sa do učenia adaptovaná z výskumu SuarezOrozca a Suarez-Orozcovej (2001) - 10 položiek. Respondenti vyjadrovali frekvenciu rôznych činností, ktoré sú potrebné na úspech v škole. Príklad: „V škole dávam pozor."

- Škála kognitívneho angažovania, ktorá bola zložená z položiek vybratých z dvoch nástrojov - 6 položiek. Položky zistovali mieru intelektovej zát’aže pri učení sa a záujem o učenie sa. Príklad: „Mám rád nové učebné výzvy.“

- Štýl domáceho učenia sa predstavoval skrátenú formu nástroja z výskumu Honga a Milgrama (2000) - 4 položky. Zistoval preferencie žiaka pri učení sa. Príklad: „Mám rád také domáce zadania, pri ktorých môžem bádat'.“

- Preferencia učebného prostredia pri učení sa doma predstavovala skrátenú formu nástroja z výskumu Honga a Milgrama (2000) - 4 položky. Položky zistovali, v akom prostredí sa žiak rád učí. Príklad: „Rád si robím úlohy za písacím stolom."

- Škála rodinných konfliktov bola adaptovaná z výskumu Prinza, Fostera, Kenta a O'Learyho (1979) - 11 položiek. Zist'ovala konfliktné situácie medzi rodičom a dietat'om ako napr. konflikty kvôli zlým známkam, množstve domácich povinností dietatáa a pod.

- Škála podporovania domáceho učenia sa žiaka rodičom bola prevzatá z výskumu Hoover-Dempseyovej et al. (2001) - 5 položiek. Príklad: „Ako často sa ti rodičia venujú pri domácom učení sa?"

- Škála násilia v škole bola prevzatá z dvoch výskumov - 7 položiek. Žiaci sa vyjadrovali, či musia robit' opatrenia, aby sa vyhli nebezpečným incidentom. Príklad: „Musím si zvolit’ náhradnú cestu domov.“

Pre úplnost' dodávame, že okrem týchto siedmich nástrojov boli použité d’alšie tri, a to originály autora. 


\subsection{Dokladovanie validity}

Zásady metodológie výskumu si vyžadujú, aby každý výskumný nástroj - to znamená aj prevzatý - mal zistenú validitu a reliabilitu v danom výskume. Je to preto, lebo je potrebné overit', či výskumný nástroj obstojí v nových výskumných podmienkach (subjekty, prostredie, špecifiká administrácie, čas, ktorý uplynul od vzniku pôvodného nástroja). Výskumník musí brat' do úvahy tieto okolnosti pri interpretácii svojich zistení. Validita a reliabilita sa nemusí zist'ovat' u štandardizovaných výskumných nástrojov, ktoré boli dostatočne vyskúšané a sú založené na reprezentatívnej výskumnej vzorke subjektov, s ktorou môže výskumník porovnat' svoj výskumný súbor a na základe toho interpretovat' svoje dáta. Autori štandardizovaných výskumných nástrojov by však mali v časovom odstupe overovat', či sú pôvodné normy ešte stále platné.

To, ako autori štúdie dokladujú postup pri validizácii svojho výskumného nástroja a ako opisujú výsledok tejto validizácie, je klúčovým údajom na posúdenie toho, či bola táto validizácia uskutočnená vhodne a korektne.

Musíme začat' zistením, či v štúdii autori vôbec uviedli údaje o validite svojich výskumných nástrojov. Vzhl'adom na to, že sme tento časopis charakterizovali ako kladúci vysoké nároky na jeho autorov, môže sa zdat' zvláštne, že $\mathrm{v}$ niektorých štúdiách tieto údaje neboli čitatelom poskytnuté. Ako uvidíme d’alej, situácia je zložitejšia.

Pokial' ide o validitu, 25,8\% štúdií malo uvedený údaj, alebo to boli štandardizované nástroje, ktoré sú validné (boli validizované predtým). Zvyšok, to znamená vel'ká väčšina výskumných nástrojov údaj o validite nemala doložený. To je nepríjemné zistenie, ktoré však môžeme rozptýlit' podrobnejšou analýzou. Našu pozornost' musíme diferencovat' podla skúmanej vlastnosti. Ak ide o vlastnost' alebo činnost', ktorá je úplne zjavná, potom je zjavná aj validita daného nástroja. Test pravopisu vo výskume Madrida et al. (2007) je vlastne diktát, pri ktorom žiaci píšu vety, ktoré im diktujú. 0 jeho validite nemožno pochybovat' ${ }^{\prime}$ a môžeme si ju overit' pohladom (face validity). Test má zrejme aj dostatočnú reliabilitu. Podobne to môžeme povedat' o rôznych testoch gramotnosti vo výskume Edmonsovej et al. (2009), kde sa použili subtesty ako pomenovanie písmen, obrázkov, aliterácia a rýmovanie.

6 Situáciu trošku zjednodušujeme. Ak dáme žiakom diktát, v ktorom je vela neznámych slov, potom to už nie je len test pravopisu, ale aj slovnej zásoby, príp. test odhadu významov, jazykového citu a pod. Tu už ide o inú vlastnost', teda aj o inú validitu. 
Inou kategóriou sú výskumné nástroje, ktoré boli adaptované (väčšinou skracované). Výskumníci validitu neskúmali, pretože dôverovali zisteniam konštruktérov o validite ich nástrojov. Vo vel'kej väčšine prípadov však zist'ovali ich reliabilitu, pretože tá závisí okrem iného aj od dížky výskumného nástroja. Ak výskumný nástroj je „katalóg“ (checklist) zist'ujúci prítomnost' alebo neprítomnost' určitých objektov, napr. materiálneho vybavenia školy, validita je vysoká a netreba ju dokladovat'. Niektoré výskumné nástroje nemali doloženú validitu, ale štúdia obsahovala plné znenie výskumného nástroja, takže čitatel' si mohol utvorit' vlastnú mienku o ňom a iní výskumníci ho mohli použit' a overit' jeho psychometrické vlastnosti.

Spôsob validizácie záleží do značnej miery od druhu výskumného nástroja. V prípade posudzovacích škál bola $\mathrm{v}$ analyzovaných štúdiách vykazovaná zvyčajne faktorová analýza, čo je správny postup. Pomocou nej sa zist’uje konštruktová validita, t. j. do akej miery sa položky tohto nástroja kryjú $\mathrm{s}$ daným konštruktom, ktorý leží v jeho základe a akú má výskumný nástroj faktorovú štruktúru (z akých dimenzií sa skladá) a či táto štruktúra zodpovedá teórii viažucej sa $\mathrm{k}$ danému konštruktu. Väčšinou sa použila exploračná faktorová analýza, $v$ menšom počte prípadov konfirmačná faktorová analýza a ešte v menšom počte prípadov obidve. Faktorová analýza však predstavuje až poslednú fázu validizácie výskumného nástroja. Tejto fáze predchádza tvorba koncepcie výskumného nástroja, zostavovanie jeho položiek, ich obsahové overovanie, postupné dolad'ovanie, zistenie, či zneniu položiek respondenti správne porozumeli atd'. Táto fáza je ovel’a dlhšia ako výpočet a interpretácia faktorovej analýzy, pretože zahŕňa aj pilotné overovanie v teréne, a to si obyčajne vyžaduje niekol'ko cyklov.

Analyzované štúdie vo vel'kej väčšine proces tvorby výskumného nástroja neopísali a vo výskumnej časti hned' prešli k údajom získaným z faktorovej analýzy (počet položiek, hranica faktorovej zát’aže položiek, počet a označenie faktorov, celková vysvetlená variancia). Výnimkou z toho trendu je napríklad štúdia Handelsmana et al. (2005), ktorí podrobne opísali proces generovania položiek nástroja. Použili však len jeden výskumný nástroj, takže mali dost' textového priestoru - opis generovania zaplnil jednu tlačenú stranu. Ak by však autori použili napríklad 6 výskumných nástrojov, ako to bolo vo výskume Shihu (2009), potom ich textový priestor na opis validizácie by bol dost' obmedzený. Shih použil konfirmačnú faktorovú analýzu a pri každom nástroji uviedol osem indexov, každý v rozsahu troch-štyroch riadkov. Dodajme, že išlo o prevzaté výskumné nástroje. 
Napriek tomu sa domnievame, že obmedzenie rozsahom textu, ktorý mohli mat' autori štúdií k dispozícii, nemusí byt' jedinou príčinou, prečo proces tvorby a validizácie nástroja neopísali podrobnejšie. V rozvinutej metodologickej kultúre sa fáza tvorby, prípravy a overovania výskumného nástroja pred faktorovou analýzou považuje za samozrejmost'. Preto sa autori sústredili hlavne na opis poslednej validizačnej fázy, teda na faktorovú analýzu a prípravnú fázu neopísali.

Aby čitatel' mohol posúdit', či bola faktorová analýza urobená dobre, je potrebné, aby štúdia poskytla podrobný opis postupu a jeho výsledkov. To bolo v štúdiách dost’ typické. Dobrým príkladom je opät' štúdia Handelsmana et al. (2005).

Cielom výskumu bolo zistit' mieru aktivity (angažovanosti, engagement) študentov na nižšom stupni vysokoškolského štúdia v USA. Na tento účel vyvinuli autori vlastnú posudzovaciu škálu, ktorá obsahovala 27 položiek. Dáta od 266 študentov podrobili exploračnej faktorovej analýze. Bola použitá metóda hlavnej osi a rotácia varimax, ktorá ponúkla štyri až sedemfaktorové riešenie. Na základe sutinového testu sa autori rozhodli pre 4 faktory, pri ktorých celková vysvetlená variancia bola $43 \%$. Autori uverejnili plné znenie položiek posudzovacej škály a faktorové zátaže v jednotlivých faktoroch (všetky nad 0,40 ). Okrem toho určili diskriminačnú validitu výskumného nástroja vzájomným korelovaním jeho dimenzií a konvergentnú validitu korelovaním skóre výskumného nástroja s prospechom študentov (tri hodnotenia študentov v priebehu semestra).

Takáto charakteristika je dostatočná na to, aby si čitatel' utvoril názor o spôsobe konštruktovej validizácie. Tu hovoríme len o požiadavkách pre časopisecké štúdie. Vo výskumných správach, v ktorých rozsah nie je obmedzený, by sa mali uviest' ešte podrobnejšie údaje. Podobné opisy validizácie poskytli mnohé štúdie v našej vzorke.

Konštruktová validita sa použila u 22 výskumných nástrojoch, z toho 7 bolo originálnych, 14 bolo prevzatých, ale validizovaných autormi štúdie na vlastnej vzorke. $V$ jednej štúdii autori prevzali nástroj, ale uspokojili sa s údajom o validite zo vzorky konštruktérov výskumného nástroja. To je samozrejme jednoduchšie, ale menej korektné riešenie.

Pokial' ide o testy, k dispozícii je len 5 údajov o validite - u jedného testu sa použila face validita, u štyroch obsahová validita. Obsah položiek navrhovaného testu posúdili odborníci, pričom sa uviedla miera ich zhody v tom, ako položky testu pokrývajú štruktúru a obsah testovanej oblasti. 
Duatepe-Paksu a Ubuz (2009) z Turecka použili vo svojom výskume dva vedomostné testy z geometrie. Ich obsahovú validitu posúdil učitel' vyučovacieho predmetu a doktorand. Kritériom bolo pokrytie učiva testovými úlohami, kognitívna úroveň úloh a ich jazyková obtažnost'. Údaje o miere zhody posudzovatelov a o tom, ako sa riešila prípadná nezhoda však autori neuviedli. Spomenuli len spôsob validizácie.

V 46 testoch sa neuviedol nijaký údaj o validite, ale ako sme už spomenuli, mnohé z nich boli štandardizované alebo uznávané (established), iné testovali oblasti, kde face validita bola jasná.

Pokial' ide o dotazník, ten sa použil v našej vzorke výskumných štúdií sedemkrát a len $v$ jednom prípade sa určila validita (obsahová), a to konsenzom učitelov a žiakov. Pri výskumných nástrojoch založených na pozorovaní a interview nebola validita udaná.

Na záver časti o dokladovaní validity výskumných nástrojov v analyzovanom časopise kategorizujeme použité možnosti. Ak zoradíme jednotlivé spôsoby validizácie podla dôkazovej sily, vychádza toto poradie. (V zátvorke sú počty výskumných nástrojov, pri ktorých sa daná validita aplikovala; pripomíname, že celkový počet nástrojov bol 174.)

1. Bola udaná konštruktová, obsahová alebo kritériálna validita (40). Pri dvoch výskumných nástrojoch autori uplatnili po dva zdroje validity.

2. Išlo o štandardizovaný nástroj, ktorý mal overenú validitu alebo to bol uznávaný (established) nástroj (5).

3. Face validita určená autormi štúdie (1).

4. Výskumný nástroj bol priložený k štúdii v plnom znení. Validita však nebola dokladovaná (10).

Prvý spôsob má najväčšiu dôkazovú silu. Validita sa určila pre konkrétny výskumný nástroj, konkrétnu vzorku subjektov a pre dané výskumné podmienky. Štandardizovaný výskumný nástroj je výborná alternatíva, ale dali sme ho na druhé miesto, pretože funguje dobre len vtedy, ked' sa výskumná vzorka a podmienky výskumu nelíšia od tých, ktoré boli pri štandardizácii. Uznávaný výskumný nástroj je taký, ktorý bol mnohokrát použitý vo viacerých výskumoch, v ktorých sa vždy potvrdila jeho validita. $S$ istou mierou neistoty jeho validita môže platit' aj v inom výskume, ktorý bol zrealizovaný za podobných podmienok aj ked' sa pri ňom výpočty neuskutočnili. Uznávaný výskumný nástroj však na rozdiel od štandardizovaného nemá k dispozícii 
normy, čiže jeho možnosti sú obmedzenejšie. Face validita je založená na kvalifikovanom hodnotení expertov; je v poriadku, ked' nejde o t'ažko identifikovatel'nú vlastnost', t. j. ked' sa od posudzovatel'ov nevyžaduje vysoký stupeň vyvodzovania, ako je to napr. pri teste vedomostí z určitého učiva geografie. Pri zložitejších vlastnostiach, ako je napríklad vnímaná zdatnost' (selfefficacy) človeka pre určitú činnost’ budú rozdiely medzi odhadom expertov väčšie. Ak je výskumný nástroj priložený k štúdii, je to lepšie ako ked' nie je dokladovaná nijaká validita. Čitatel' môže jeho validitu preskúmat'. Existuje tiež šanca, že sa použije v iných výskumoch, kde sa jeho validita overí.

\subsection{Dokladovanie reliability}

Výskumný nástroj musí byt’ dostatočne reliabilný, aby s ním mohol výskumník pracovat', a preto je reliabilita výskumného nástroja rovnako dôležitá vlastnost' ako validita. Údaj o reliabilite bol uvedený u 79,6 \% výskumných nástrojov.

Najviac bolo zastúpené vyjadrenie vnútornej homogenity výskumného nástroja pomocou koeficientu alfa - asi preto, lebo sa výhodne používa pri posudzovacích škálach, čo bol najčastejší typ výskumného nástroja. Koeficient alfa bol uvedený pri 91 nástrojoch. Z nich 31,7 \% boli originálne nástroje autorov štúdií, 58,3 \% tvorili prevzaté nástroje, ktoré však autori štúdií reliabilizovali na vlastnej vzorke respondentov, a len v $10 \%$ prípadov sa autori štúdií uspokojili s reliabilitou, ktorú uviedli konštruktéri nástroja pri vlastnej vzorke respondentov. Tretí spôsob je najmenej vhodný. Samozrejme, ešte horší prípad je neuvedenie nijakého údaju o reliabilite (16 nástrojov). Za komentár stojí najmä vysoký počet výskumných nástrojov, ktoré boli prevzaté a reliabilizované v nových podmienkach. To je vel'mi dobrá stratégia, pretože, ako sme uviedli, v nových podmienkach sa nástroj môže správat' odlišne, a preto jeho psychometrické vlastnosti je potrebné vždy overit'. Koeficient alfa sa v analyzovaných štúdiách pohyboval väčšinou nad 0,80 , teda dostatočne vysoko.

Na druhom mieste pokial' ide o frekvenciu spôsobu zist'ovania reliability bola zhoda medzi posudzovatel'mi (inter-rater), a to pri 21 výskumných nástrojoch. Použili sa jednak pri metóde pozorovania, jednak pri testoch. V druhom prípade išlo o úlohy, v ktorých sa skórovali odpovede na viacstupňovej škále. Pri takýchto typoch testových úloh je vždy vhodné si overit', či sa tá istá odpoved' vyhodnocuje rovnako. Zhoda medzi posudzovatel'mi (po zacvičení) bola vel'mi vysoká - nad 0,90. Zist'ovanie reliability opakovaným meraním po 
časovom odstupe (test-retest) sa uplatnilo najmä vo výskumoch, kde subjekty prešli intervenciou (typicky vo vyučovacom experimente) a zist'ovalo sa, či merací nástroj na pretest-posttest zostal dostatočne reliabilný aj na konci intervencie. Použité nástroje boli testy, posudzovacie škály, dotazníky alebo pozorovacie schémy (16 nástrojov). Reliabilita sa pohybovala od 0,68 do 0,95, väčšinou však nad 0,80.

Metodologické učebnice väčšinou uvádzajú minimálnu požiadavku 0,80 na reliabilitu výskumného nástroja. Koeficient 0,70 už naznačuje, že nástroj má isté problémy (Kline, 2000, s. 13-15). Pri údaji 0,60 je potrebné k výskumnému nástroju pristupovat' opatrne. Pri štandardizovaných testoch, ktoré sú dostatočne overené, je namieste požiadavka 0,90 a vyššia (Hopkins, 1998).

Toto sú učebnicové odporúčania. Výskum sa však uskutočňuje v konkrétnych podmienkach, ktoré ovplyvňujú reliabilitu, a preto údaj o reliabilite je potrebné interpretovat' vždy z hladiska týchto podmienok. Nástroje mávajú rôznu reliabilitu vzhl'adom na l'udské vlastnosti, ktoré merajú. Test vedomostí z daného okruhu učiva by mal mat' spravidla vyššiu reliabilitu ako posudzovacia škála záujmov a postojov a tá vyššiu ako test tvorivosti. Vplyvným faktorom je tiež obtažnost' položiek nástroja. Preto je vel'mi dôležité, aby výskumník svoj nástroj opísal dost' podrobne, aby si čitatel' o ňom utvoril plastický obraz. Dobrou praxou je pripojit' k štúdii plné znenie výskumného nástroja (bolo to v osemnástich štúdiách) alebo aspoň ukážky položiek (vel'mi často). Niekde bol opísaný celý vývoj výskumného nástroja, i ked' sa redakcia vyhýba uverejňovat' takéto štúdie.

Ďalším faktorom, ktorý ovplyvňuje reliabilitu, je vel'kost' a charakter výskumnej vzorky. Je známe, že u homogénnej vzorke býva reliabilita nižšia ako u nehomogénnej vzorke a vice versa. Test študijných schopností má u žiakov základnej školy vyššiu reliabilitu ako u žiakov gymnázia, pretože vzorka žiakov gymnázia je z hladiska študijných schopností homogénnejšia ako u žiakov základnej školy. Pohl'ad na rozptyl skóre tiež pomôže interpretovat', prečo je reliabilita nízka. $\mathrm{V}$ každej z analyzovaných štúdii bola výskumná vzorka opísaná vel'mi podrobne, a to nielen z hladiska lokality, veku a genderu subjektov, ale aj ich etnickej príslušnosti. Ak to bolo potrebné z hladiska zamerania štúdie, uviedli sa aj d'alšie ukazovatele, napr. poberanie školskej stravy zadarmo alebo za zníženú cenu, ako ukazovatel' sociálno-ekonomického statusu rodiny, percento detí so špeciálnymi potrebami, postihnutím, materinským jazykom iným ako angličtina a pod. 
Počet položiek v nástroji je d’alším determinantom reliability. Dlhšie nástroje majú spravidla vyššiu reliabilitu ako kratšie nástroje. Dôležité je tiež rozlišovat', kedy autori uvádzajú reliabilitu za celý nástroj a kedy za jednotlivé dimenzie, pretože tie majú nárok na nižšiu reliabilitu. Dížka však nie je jediná vlastnost' nástroja, ktorá ovplyvňuje reliabilitu. Tá tiež závisí od počtu dimenzií, vel'kosti ich vzájomnej korelácie a priemeru interkorelácií položiek v celom nástroji.

Seitsingerová (2005) použila vo svojom výskume nástroj nazvaný Classroom Instructional Practice Scale, ktorý zist’oval, v akej miere učitelia v USA pokrývajú predpísané učivo a aká je štruktúra ich vyučovacích postupov a stratégií. Išlo o sebahodnotiaci, prevzatý nástroj. Mal 16 dimenzií (napr. vyučovanie v malých skupinách, rozvoj kritického myslenia, komunitné učivo, vyučovanie občianskych a sociálnych zručností, učenie o zdraví, využívanie literárnych zdrojov a pod.). Celková reliabilita bola vel'mi vysoká $(0,95)$ zrejme aj preto, lebo nástroj bol vel'mi dlhý, obsahoval 86 položiek. Reliabilita jednotlivých dimenzií bola v rozmedzí 0,24 a 0,79 (nie je udané, kol'ko položiek mali dimenzie).

\subsection{Porovnanie vyjadrovania validity a reliability}

Základným zistením je, že reliabilita bola vyjadrovaná ovel’a častejšie ako validita, pričom pomer je približne $3: 1$. Prevahu vyjadrovania reliability môžeme vysvetlit' jednoduchším spôsobom jej zistovania najmä pri posudzovacích škálach, ktoré tvorili najfrekventovanejší výskumný nástroj. Niektorí autori zistovali reliabilitu výskumného nástroja viacerými metódami, pričom väčšinou použili výpočet vnútornej konzistencie a stability. Na druhej strane pri zistovaní validity výskumných nástrojov sa viaceré spôsoby použili málokedy - konštruktová spolu so súbežnou len dvakrát, konštruktová spolu s diskriminačnou trikrát. Tento nízky počet tiež dokumentuje situáciu validity v porovnaní s reliabilitou výskumných nástrojov.

\section{Diskusia}

Naším ciel'om bolo posúdit' validitu a reliabilitu výskumných nástrojov, ktoré boli použité vo vybraných štúdiách daného časopisu. Z piatich otázok položených na začiatku výskumu, na ktoré sme hladali odpovede, priniesli tri také informácie, ktoré neboli celkom predpokladané.

Pokial' ide o druhy výskumných nástrojov v skúmaných štúdiách, bolo prekvapením vel'mi vysoké zastúpenie posudzovacích škál a testov, ktoré pokryli 
takmer $91 \%$ použitých výskumných nástrojov. Výskumník si volí výskumný nástroj podla ciela svojho výskumu, ale svoj výskumný ciel' si nastavuje aj podla dostupných výskumných nástrojov. Nemôže si totiž stanovit' ciel', na riešenie ktorého nemá inštrumentálne možnosti. Do hry pri vol'be výskumných nástrojov vstupuje aj pragmatický aspekt. Posudzovacie škály a testy majú výborné možnosti hromadnej administrácie, dobré štatistické možnosti a možnosti zistovania reliability (v porovnaní s interview a pozorovacími schémami). To ich zrejme favorizovalo pri výbere do konkrétnych výskumov. Vel'ké množstvo hotových posudzovacích škál a testov, ktoré autori štúdií prevzali z iných výskumov zdôvodňuje ich frekventovaný výber. Navyše, ako sme ukázali, výskumníci pristupovali k prevzatým nástrojom vel'mi flexibilne - skracovali ich, kombinovali, zlučovali viaceré nástroje tak, aby to vyhovovalo ciel'om výskumu.

Nepredpokladaným zistením bol vel'ký počet výskumných nástrojov v jednom výskume, čo ukazuje, že autori riešili komplexné, široké otázky, na zodpovedanie ktorých nevyhnutne potrebovali viaceré výskumné nástroje. Použili viaceré premenné, medzi ktorými hl'adali vztahy a spojenia. Túto snahu môžeme vsadit' do širšieho koncepčného rámca kvantitatívneho výskumu. Disman (1993) vo svojej téze o informačnej redukcii vyjadruje myšlienku, že žiadny výskum nemá možnost' uchopit' realitu v plnosti, pretože je nesmierne zložitá. Preto ju redukuje na skúmatel'ný úsek, zložky alebo rovinu. Nasadenie vel'kého množstva premenných a početných výskumných nástrojov v skúmaných štúdiách je snahou zmiernit' uvedenú redukciu informácií a postupnými krokmi sa priblížit’ k plnšiemu opisu reality.

Tretia výskumná otázka sa týkala spôsobu validizácie a reliabilizácie výskumných nástrojov. Zistenia zodpovedali cielom výskumu a možnostiam výskumných nástrojov. Najfrekventovanejším spôsobom validity bola konštruktová validita. Tu sa na chvílu zastavíme. Ako je známe, tvorba výskumného nástroja (pre zjednodušenie budeme mat' na mysli len posudzovacie škály) prebieha tak, že výskumník na základe svojej interpretácie príslušného konštruktu zostaví položky výskumného nástroja a podrobí ich validizácii pomocou faktorovej analýzy (pred ňou ešte uskutoční položkovú analýzu). Tu je potrebné pripustit', že faktorová analýza by mala s istou pravdepodobnost'ou potvrdit' autorovu interpretáciu, ved' dané položky nástroja vznikli na jej základe (a nevhodné boli eliminované v procese položkovej a faktorovej analýzy). To ukazuje, že proces konštruktovej validizácie je akoby uzavretý do seba a sám seba potvrdzuje. Na to, aby autor zistil, či konštrukt dobre interpre- 
toval pri navrhovaní položiek svojho výskumného nástroja a či boli položky dobre sformulované, by sa mal presvedčit' ešte zistením súbežnej a diskriminačnej validity. $V$ prvom prípade ide o zistenie, či jeho výskumný nástroj dobre koreluje s inými nástrojmi, ktoré merajú totožný konštrukt. V druhom prípade ide o zistenie, či jeho výskumný nástroj nízko alebo záporne koreluje s výskumným nástrojom, ktorý meria úplne odlišný konštrukt. Týmto postupom by sa dokazovací kruh otvoril a konštruktová validita by sa mohla považovat' za dokázanú. Ako sme uviedli v časti 4.6, súbežná a diskriminačná validita sa však zistovala len $v$ niekol'kých prípadoch, čo považujeme za slabinu validizačného procesu v skúmaných štúdiách.

Doklad o validizácii a reliabilizácii použitého výskumného nástroja (štvrtá otázka) je dôležitou informáciou vedúcou k zisteniu, či sa uskutočnila vhodne a korektne. Čitatel' časopisu by mal mat' dostatok relevantných informácii o tom, ako validizácia a reliabilizácia prebehla a aký mala výsledok, aby mohol úroveň výskumu hodnotit’ a interpretovat'. S prekvapením sme však zistili, že takmer tri štvrtiny výskumných nástrojov nemalo uvedený údaj o validite, a tým ani o spôsobe validizácie. $V$ texte sme vysvetlili, že tento na prvý pohlad hrubý nedostatok možno zmiernit', ked' sa na výskumné nástroje pozrieme podrobnejšie. Mnohé z nich mali zrejmú (face) validitu, a to často formálne (expertne) potvrdenú. Osemnást' výskumných nástrojov (zo 174) bolo doložených in extenso; ak tak nebolo a išlo o nový nástroj, autori obyčajne uviedli aspoň príklady položiek. To je dobrý krok umožňujúci čitatelovi posúdit' validizáciu daného výskumného nástroja. Reliabilita bola dokumentovaná častejšie ako validita, čo možno pripísat’ okrem iného pohodlnej možnosti jej zist'ovania u posudzovacích škál a testov, najfrekventovanejších výskumných nástrojov v našej vzorke štúdií.

Pokial' ide o piatu otázku, či bola validita a reliabilita použitých výskumných nástrojov dostatočne vysoká, odpoved' je pozitívna. Vel'ká väčšina výskumných nástrojov mala koeficient reliability 0,80 a vyšší; jednotlivé dimenzie výskumných nástrojov však mali niekedy reliabilitu nižšiu, a to najmä kvôli menšiemu počtu položiek. Vysoká reliabilita výskumných nástrojov je dobrou správou, pretože ona je aj nevyhnutnou podmienkou ich dostatočnej validity (Kline, 2000, s. 15).

Pri celkovom hodnotení psychometrickej stránky výskumných nástrojov v našom výbere štúdií môžeme konštatovat’ vel'mi dobrú úroveň. Ak sa vyskytli odchýlky od požadovaných princípov, tieto boli prirodzené a zdôvodnitel'né. Ukázala sa tiež stabilita postupov validizácie a reliabilizácie v čase. 
Analyzované štúdie pokryli obdobie šiestich rokov; počas ktorých sme nezistili zmeny trendu v žiadnej zo skúmaných otázok tohto výskumu.

Zostáva ešte vyjadrit' sa k motivácii tohto príspevku vyjadreného na jeho začiatku - či v podmienkach dynamického rozvoja metodológií zostali klasické postupy vyjadrovania validity a reliability výskumných nástrojov stabilné. Pohl'ad do analyzovaných čísiel časopisu ukazuje, že piliere kvantitatívnych výskumov zostali neporušené. Validita a reliabilita zostávajú nevyhnutnou súčastou dobrých kvantitatívnych výskumov, ale pri jej posudzovaní je potrebné prihliadat' k špecifickým podmienkam a možnostiam konkrétneho výskumu.

V texte sme sa vyhli explicitnému porovnávaniu validity a reliability výskumných nástrojov $\mathrm{v}$ analyzovaných štúdiách so situáciou $\mathrm{v}$ našich pedagogických časopisoch - a ani v tomto závere to nemienime urobit'. Nielen preto, že k dispozícii nemáme príslušné údaje na komparáciu, ale aj preto, lebo sa obávame, že mechanické porovnávanie s výskumami, ktoré vznikli za iných podmienok skrýva v sebe mnoho nástrah. Tým však netvrdíme, že by sa takáto analýza nemohla uskutočnit’. V prvej aproximácii by sa však mala dat' prednost' analýze na „vnútroštátnej“ úrovni.

\section{Literatúra}

Bang, H. J. (2011). Newcomer immigrant students' perspectives on what affects their homework experiences. The Journal of Educational Research, 104(6), 408-419.

Disman, M. (1993). Jak se vyrábí sociologická znalost. Praha: Vydavatelství Karolinum.

Duatepe-Paksu, A., \& Ubuz, B. (2009). Effects of drama-based geometry instruction on student achievement, attitudes, and thinking levels. The Journal of Educational Research, 102(4) 272-286.

Edmonds, E., O'Donoghue, C., Spano, S., \& Algozzine, R. F. (2009). Learning when school is out. Journal of Educational Research, 102(3), 213-221.

Elliot, J. (2012). Using narrative in social research. Qualitative and quantitative approaches. Los Angeles: Sage.

Handelsman, M. N., Briggs, W. L., Sullivan, N., \& Towler, A. (2005). A measure of college student course engagement. Journal of Educational Research, 98(3), 184-189.

Hendl, J. (2005). Kvalitatívní výzkum. Základní metody a aplikace. Praha: Portál.

Hong, E., \& Milgram, R. M. (2000). Homework: Motivation and learning preference. Westport, CT: Bergin \& Garvey.

Hoover-Dempsey, K. V., Battiato, A. C., Walker, J. M., Reed, R. P., De-Long, J. M., \& Jones, K. P. (2001). Parental involvement in homework. Educational Psychologist, 36(3), 195-209.

Hopkins, K. D. (1998). Educational and psychological measurement and evaluation, $8^{\text {th }}$ edition. Boston: Allyn and Bacon. 
Janík, T., \& Miková, M. (2006). Videostudie: výzkum výuky založený na analýze videozáznamu. Brno: Paido.

Kline, P. (2000). Handbook of psychological testing. $2^{\text {nd }}$ edition. London: Routledge.

Koh, C. K., Wang, J., Tan, O. S., Liu, W.C., \& Ee, J. (2009). Bridging the gaps between students' perceptions of group project work and their teachers' expectations. Journal of Educational Research, 102(5), 334-347.

Madrid, L. S., Canas, M., \& Ortega-Medina, M. (2007). Effects of team competition versus team cooperation in classwide peer tutoring. Journal of Educational Research, 100(3), 155-160.

Najvar, P., Najvarová, V., Janík, T., \& Šebestová, S. (2011). Videostudie v pedagogickém výskumu. Brno: Paido.

Prinz, R. J., Foster, S. L., Kent, R. N., \& O'Leary, K. D. (1979). Multivariate assessment of conflict in distressed and non-distressed mother-adolescent dyads. Journal of Applied Behavior Analysis, 12(4), 691-700.

Salvia, J., \& Ysseldyke, J. E. (1998). Assessment. $7^{\text {th }}$ edition. Boston: Houghton Mifflin Company.

Seitsinger, A. (2005). Service learning and standards-based instruction in middle schools. Journal of Educational Research, 98(1), 19-30.

Shih, S. S. (2009). An examination of factors related to Taiwanese adolescents' reports of avoidance strategies. Journal of Educational Research, 102(4), 377-388.

Standards for educational and psychological testing. (1999). Washington: American Educational Research Association.

Suarez-Orozco, C., \& Suarez-Orozco, M. (2001). Children of immigration. Cambridge, MA: Harvard University Press.

\section{Autor}

Prof. PhDr. Peter Gavora, CSc., Univerzita Tomáše Bati ve Zlíně, Fakulta humanitních studií, Centrum výzkumu, Mostní 5139, 76001 Zlín, e-mail: gavora.p@gmail.com

\section{Validity and reliability of research instruments: Principles and actual practice}

Abstract: The aim of the paper was to explore how principles of estimating validity and reliability of research instruments, as described in respected methodology textbooks, are satisfied. The initial parts of the paper delineate the theoretical framework and describe the concepts of validity and reliability. The following sections of the paper explain the process of analysis and its findings. The Journal of Educational Research was chosen as the research focus. A sample of 56 randomly selected articles from it has been inspected. The analysis revealed that a large majority (91\%) of research instruments used in these articles was scales and tests, the rest were questionnaires, observation schemes and interviews. Surprisingly, validity was calculated only with 26 of instruments; the rest of instruments were standardized tests or they were face- 
validated. As far as scales are concerned, construct validity was documented by means of factor analyses. Content validity and face validity were used in tests, questionnaires and interviews. We consider the infrequent use of combination of two sources of validity (e.g., construct and concurrent or discriminant) to be a weak element in the validation processes in the sample of studies. Reliability was documented with $80 \%$ of research instruments. The most frequent method of calculation was Cronbach's alpha. Inter-rater reliability was used in observations and tests; test-retest reliability was used to control the stability of the pretest-posttest measuring instrument. The size of reliability coefficients in most of studies exceeded 0.80 . Throughout the analysis it was corroborated that when judging validity and reliability one has to critically consider the specific conditions of each research study before expressing an evaluation statement.

Keywords: metastudy, validity, reliability, research instrument, research study

Krejčí, J., \& Leontiyeva Y. (Eds.). (2012). Cesty $k$ datům. Zdroje a management sociálněvědních dat $v$ České republice. Praha: SLON.

Prostředí pro vědeckou práci v sociálních vědách prochází překotným vývojem. Jedním z důvodů je také rostoucí objem dat, která jsou k dispozici pro sociální analýzy. Využívání nových možností i zpřístupňování vlastních databází bývá podmínkou pro plnohodnotné zapojení do života mezinárodní vědecké komunity a pro dosahování výsledků s uznávaným vědeckým impaktem. Efektivní práce s daty však vyžaduje orientaci $\mathrm{v}$ nepřehledném množství zdrojů, zvládnutí metod managementu dat a sekundární analýzy i orientaci v právních a formálních náležitostech sdílení dat mezi výzkumnými týmy. Autoři a autorky této knihy se právě proto zaměřují na problematiku vytváření a používání kvantitativních sociálních dat, věnují se metodám managementu dat a představují služby datových archivů. Zvláštní pozornost věnují problematice harmonizace dat pro účely časových a mezinárodních komparací. Velkou část knihy tvoří přehledové studie o dostupných datech včetně hlubších rozborů a analýz datových zdrojů k vybraným tématům. Kniha je primárně zaměřena na akademický sociální výzkum, své čtenáře si ale jistě najde i ve výzkumu pro potřeby státní administrativy, v soukromých výzkumných agenturách i mezi novináři a všemi, kteří pracují s výstupy sociálních výzkumů. Jaké jsou zdroje dat v sociálních vědách? Kde hledat a jak získat data z předchozích šetření a sociálních statistik? Jak úspěšně realizovat vlastní výzkumný projekt? Jakých mezinárodních šetření se zúčastnila Česká republika? Jsou data z mezinárodních šetření srovnatelná? Jak měřit vzdělání a sociální postavení tak, aby byly výsledky srovnatelné? Kde najít data o gramotnosti populace, politických postojích, názorech na náboženství, manželství a rolích v rodině nebo data o migraci? Jaké databáze vytváří Český statistický úřad a k čemu jsou využitelné? 